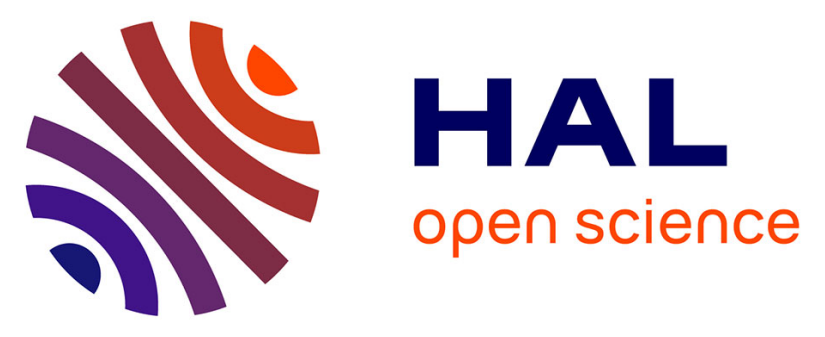

\title{
Hepatic nodular lymphoid lesion with increased IgG4-positive plasma cells associated with primary biliary cirrhosis: a report of two cases
}

Jessica Calvo, Nicolas Carbonell, Olivier Scatton, Christophe Marzac, Nathalie Ganne-Carrie, Dominique Wendum

\section{To cite this version:}

Jessica Calvo, Nicolas Carbonell, Olivier Scatton, Christophe Marzac, Nathalie Ganne-Carrie, et al.. Hepatic nodular lymphoid lesion with increased IgG4-positive plasma cells associated with primary biliary cirrhosis: a report of two cases. Virchows Archiv, 2015, 467 (5), pp.613-617. 10.1007/s00428015-1841-5 . hal-01290022

\section{HAL Id: hal-01290022 https://hal.sorbonne-universite.fr/hal-01290022}

Submitted on 17 Mar 2016

HAL is a multi-disciplinary open access archive for the deposit and dissemination of scientific research documents, whether they are published or not. The documents may come from teaching and research institutions in France or abroad, or from public or private research centers.
L'archive ouverte pluridisciplinaire HAL, est destinée au dépôt et à la diffusion de documents scientifiques de niveau recherche, publiés ou non, émanant des établissements d'enseignement et de recherche français ou étrangers, des laboratoires publics ou privés. 


\section{Hepatic nodular lymphoid lesion with increased IgG4-positive plasma cells associated with primary biliary cirrhosis: a report of two cases}

$\underline{\text { Jessica Calvo }}^{(1)(6)}$, $\underline{\text { Nicolas Carbonell }}^{(2)}$, $\underline{\text { Olivier Scatton }}^{(\text {(1) (6) }}{ }^{(6)}, \underline{\text { Christophe Marzac }}^{(4)}$, Nathalie Ganne-Carrie $^{(5)}$, Dominique Wendum ${ }^{(1)(6)}$

Author Affiliations

1. Department of Pathology, AP-HP Hôpital Saint-Antoine, 184 rue du Faubourg SaintAntoine, F-75012, Paris, France

6. Sorbonne Universités, UPMC, Univ Paris 06, Paris, France

2. Department of Hepatology, AP-HP Hôpital Saint-Antoine, 184 rue du Faubourg SaintAntoine, F-75012, Paris, France

3. Department of Liver Surgery and Transplantation, AP-HP Hôpital Saint-Antoine, 184 rue du Faubourg Saint-Antoine, F-75012, Paris, France

4. Department of Laboratory Hematology, AP-HP Hôpital Saint-Antoine, 184 rue du Faubourg Saint-Antoine, F-75012, Paris, France

5. Department of Hepatology, AP-HP Hôpital Jean Verdier, avenue du 14 juillet, F-93140, Bondy, France

\section{Introduction}

Nodular lymphoid lesion of the liver, also called nodular reactive lymphoid hyperplasia or pseudolymphoma is a rare condition that appears as liver nodules. Typically, it affects adult women and can be associated with an autoimmune disease, chronic hepatitis or a past history of malignancy. The pathogenesis of this lesion is so far unknown and is suggested to be autoimmune [1-3]. Histologically, it consists of lymphoid tissue with lymphoid follicles, a dense lymphoplasmacytic infiltrate and clusters of epithelioid cells. The main differential diagnosis is low grade B-cell lymphoma, particularly marginal zone B-cell lymphoma [4]. Recently, some reactive lymphoid infiltrates with an increased number of IgG4 positive (+) plasma cells have been associated to IgG4-related disease [5, 6].

We herein report the first two cases of reactive lymphoid hyperplasia of the liver with an increased number of IgG4+ plasma cells in patients with primary biliary cirrhosis (PBC). We will discuss the relationship of these lesions with IgG4-related disease.

\section{Clinical History}

Case 1

A 70-year-old woman with a history of PBC presented with abdominal pain. She underwent an abdominal ultrasound which revealed a $23 \mathrm{~mm}$ left lobe liver nodule. 
PBC was diagnosed six years before by the presence of cholestasis with type M2 antimitochondrial antibodies (> 1/640). Rheumatoid factor antibodies, Sjögren syndrome-A antibodies, Sjögren syndrome-B antibodies and antinuclear antibodies were negative. Hepatitis B and C serologies were negative. A liver biopsy performed at that time showed a Ludwig's stage 2 PBC. The patient was treated with ursodeoxycholic acid (15mg/kg/day) leading to the normalization of liver function tests (bilirubin, alkaline phosphatase, $\gamma$-glutamyltransferase, aspartate aminotransferase, alanine aminotransferase).

On the MRI, the lesion measured $23 \mathrm{~mm}$, was enhanced at the arterial phase with no wash out at the portal phase (figure 1a and 1b). The liver was not dysmorphic and there was no sign of portal hypertension. On the PET-scan, the lesion appeared hypermetabolic without any other hypermetabolic foci. Alpha-fetoprotein and carcinoembryonic antigen serum levels were within normal ranges. Resection of the left lobe of the liver was performed.

Two years after the surgical resection, the patient had a lobular breast carcinoma treated by surgery, radiotherapy and letrozole. No other particular event occurred within the 3-year follow-up.

IgG4-related disease was not found in other organs and IgG4 serum levels measured after surgery were normal $(<140 \mathrm{mg} / \mathrm{dL})$.

\section{Case 2}

An 80-year-old woman with a history of PBC diagnosed 2 years before underwent a routine liver ultrasound, which revealed a $13 \mathrm{~mm}$ hypoechoic right liver nodule. PBC was diagnosed by the presence of cholestasis with type M2 antimitochondrial antibodies (1/640). A liver biopsy was performed and showed a Ludwig's stage 2 PBC. The patient was treated with ursodeoxycholic acid $(15 \mathrm{mg} / \mathrm{kg} /$ day $)$, leading to liver function tests normalization.

The patient was also diagnosed with Sjögren syndrome with xerostomia and positive Sjögren syndrome antibodies. The CT scan and MRI showed an arterial phase enhancement of the liver lesion with a portal phase wash out, suggesting hepatocellular carcinoma (figure $2 \mathrm{a}$ and $2 \mathrm{~b}$ ). A biopsy of the lesion followed by radiofrequency ablation was performed. A concomitant biopsy in the non-tumoral liver was also performed. Three years after radiofrequency ablation, there was no recurrence.

IgG4- related disease was not found in other organs and IgG4 serum levels, measured after radiofrequency ablation, were normal ( $<140 \mathrm{mg} / \mathrm{dL})$.

\section{Materials and Methods}

Formalin fixed pararffin embedded (FFPE) tissues were cut into $3 \mu \mathrm{m}$-thick sections and were submitted for H\&E, Ziehl-Neelsen, Gomori-Grocott, orcein stainings, immunohistochemistry (IHC) and in-situ hybridization. IHC was performed using a Bond-Max automated immunostainer (Leica Microsystems) using the following antibodies with prior antigen retrieval (10mM citrate buffer pH 6): CD3 (Neomarker, 1:300), CD5 (Novocastra, 1/50), CD20 (Novocastra, 1:350), CD21 (Novocastra, 1:100), CD23 (Novocastra, 1:50), CD43 (Dako, 1:75), CD138 (Dako, 1:100), IgG4 (Binding Site, 1:200), IgG ( Dako, 1:1000), kappa (DB-Biotech, 1:500), and lambda (DB-Biotech, 1:2000) light chains. Epstein Barr virus (EBV) detection was performed by in-situ hydridization using an EBV-encoded RNA probe (EBER) (Leica, ISH EBER ready to use oligonucleotide probe) IgG4+ plasma cells were counted on the three HPFs $\left(x 400,0.24 \mathrm{~mm}^{2}\right.$ per field $)$ with the highest number 
of IgG4+ plasma cells, and the average was determined. IgG plasma cells were counted in the same way on the same three fields to provide the $\mathrm{IgG} 4 / \mathrm{IgG}$ ratio [7].

DNA was extracted from the FFPE tissue (QIAsymphony DSP DNA Mini Kit, Qiagen). Clonal immunoglobulin heavy chain rearrangement was searched by using three VH-JH fluorescent multiplex PCR followed by fragment length analysis, according to BIOMED-2 standardization protocol [8].

\section{Results}

Case 1

Grossly, the lesion measured 18mm, appeared white, homogeneous and well circumscribed (figure 1c). Histologically, it consisted of lymphoid follicles with a dense lymphoplasmacytic infiltrate containing abundant regular plasma cells and clusters of epithelioid histiocytes, forming grannulomas (figure 1d). Fibrous tissue was scarce within the lesion, with no storiform pattern. Obliterative phlebitis was not identified.

No infectious pathogen was identified on Ziehl-Neelsen and Gomori-Grocott stainings. IHC profile showed a majority of CD138+ cells, with CD20+ and CD3+ small lymphocytes. There was no abnormal expression of CD5 or CD23. The Kappa/Lambda ratio of plasma cells was normal with a polyclonal pattern. EBV encoded small RNAs were not detected. The IgG4+ plasma cell count was 82 per HPF (figure 1e) and the IgG4/IgG ratio was $>40 \%$. There was no rearrangement of immunoglobulin heavy chains using FR1/JH, FR2/JH, and FR3/JH primers in the lymphoid tissue. In the non-tumoral liver, there were a few fibrous septa, mild steatosis, lymphoplasmacytic portal inflammation with lymphocytic destructive cholangitis (figure 1f) and mild interface hepatitis suggestive of stage 3 PBC. There were no IgG4+ plasma cells in the non-tumoral liver (figure 1g)

\section{Case 2}

The histological examination of the biopsy specimen showed the same pattern as in case 1, with abundant nonatypical plasma cells and small lymphocytes. There were some epithelioid cells and a slight non storiform fibrosis (figure 2c). The Kappa/Lambda ratio of plasma cells was normal with a polyclonal pattern. The IgG4+ plasma cells count was 76 per high power field and the IgG4/ IgG ratio was $>40 \%$. The non-tumoral liver biopsy showed a Ludwig's stage 2 PBC with a dense portal lymphoplasmacytic infiltrate, lymphocytic and granulomatous cholangitis (figure 2e), moderate interface hepatitis and periportal fibrosis without bridging. There were no IgG4+ plasma cells in the non-tumoral liver (figure $2 \mathrm{f}$ ).

\section{Discussion}

These two cases of nodular lymphoid lesions of the liver. showed a typical histological aspect with a dense lymphoplasmacytic infiltrate, lymphoid follicles, and epithelioid granulomas with no rearrangement of immunoglobulin heavy chains using FR1/JH, FR2/JH [1-3]. However, there were abundant IgG4+ plasma cells within these lesions, which, to our knowledge, has not been previously described in nodular lymphoid lesions of the liver.

Our observations led us to consider whether these lesions may be manifestation of IgG4-related disease or not. Importantly, an increasing number of lesions rich in IgG4 + plasma cells have been identified since the concept of IgG4-related disease has emerged. However, these lesions do not always belong to the spectrum of IgG4- 
associated systemic disease. For instance, abundant IgG4+ plasma cell infiltrate has been identified in primary sclerosing cholangitis, inflammatory bowel disease, rheumatoid arthritis and carcinomas [9-12].

The diagnosis of IgG4-related disease is based on a set of both clinical and histopathological features. The typical histological features combine a dense lymphoplasmacytic infiltrate with abundant IgG4+ plasma cells, storiform fibrosis and obliterative phlebitis [7, 13]. Nevertheless, some lesions are suggested to belong to the spectrum of IgG4-related disease even though they have atypical histological aspects [14, 15].

In our two cases, despite a dense lymphoplasmacytic infiltrate with an increased number of IgG4+ plasma cells (> 50/HPF on gross specimen, and > 10/ HPF on biopsy with a IgG4/IgG ratio > 40\%), some characteristic features of IgG4-related disease were missing - i.e. lack of significant fibrosis and obliterative phlebitis. According to Deshpande et al. diagnostic criteria for IgG4-related disease, our cases belong to the «probable histological feature of IgG4-related disease » category [7]. To be more consistent, the diagnosis of IgG4-related disease requires additional clinical, radiological and/or serological evidence. They were all missing in our cases: the serum levels of IgG4 were normal at the time of local ablation of the focal lesion and the patients had no other organ manifestation of IgG4-related disease, in particular no pancreatic, biliary, salivary, cutaneous or pulmonary lesion, either at baseline or 3 years after local treatment.. The response to corticosteroid therapy can also be a strong argument to underpin the diagnosis of IgG4-related disease, but it could not be assessed in our cases since the lesions were ablated.

The histological features in our cases also included the presence of prominent granulomas. Granulomas are usually regarded as a feature that is not seen in IgG4-related disease. In most settings their presence would make this diagnosis very unlikely, even though Bateman et al. recently highlighted the fact that granulomas may be seen in lymph nodes in IgG4-related disease [15].

The pathological aspects of the non-tumoral liver in our cases did not provide any evidence for liver IgG4 hepatopathy. According to Umemura et al., histological findings in the liver of patients with IgG4-related pancreatitis can have several patterns: 1) a portal inflammation pattern, with intense portal inflammation with or without interface hepatitis; 2) a large duct damage pattern, characterized by bile ductular proliferation, neutrophilic infiltration and edematous change in the portal areas; 3) a portal sclerosis pattern, exhibiting dense portal sclerosis with scarce portal inflammation; 4) a lobular hepatitis pattern, showing lobular inflammation with hepatocellular necrosis resembling viral hepatitis; or 5) a cholestatic pattern, with canalicular cholestasis predominantly in the centrilobular area [16]. A perivenular accentuation of the portal infiltrate and portal based fibroinflammatory nodules have also been described in the liver of patients with IgG4-related cholangitis [17]. The only common feature in all these patterns is a prominent IgG4+ plasma cell infiltrate.

In our cases, the pathological aspects of the non-tumoral liver could be consistent with the portal inflammation pattern, but its lack of IgG4+ plasma cells, combined with granulomatous cholangitis and typical serum immunological abnormalities (Anti-mitochondrie M2 antibodies > 1/640), precludes the diagnosis of liver IgG4-related disease and was typical of PBC [16, 17].

All these arguments suggest that our lesions may not be a manifestation of IgG4-related disease. However, conversely, it has been suggested that pulmonary pseudolymphoma might be a form of IgG4-related sclerosing disease with no other typical feature than a rich IgG4+ plasma cell infiltrate and a high IgG4/IgG ratio [6]. The 
histological findings of this lung lesion have many similarities with our cases, namely lymphoid follicles with a variable degree of fibrosis, sheets of interfollicular plasma cells and the absence of obliterative phlebitis.

A specific finding in our two lesions was their occurrence in patients with PBC. Whereas reactive nodular lymphoid hyperplasia has been described to be associated with PBC, IgG4+ plasma cell infiltrates have not been identified in PBC livers [18]. The Th1 and Th17 signaling pathways have been associated with the pathogenesis of PBC [19]. By contrast, the immunological profile of IgG4-related disease is a $\mathrm{T}_{\mathrm{h}} 2$-cell-dominant immune response in affected sites and in peripheral blood T-cell lymphocytes [20,21]. However, the pathogenesis of an IgG4+plasma cell rich lesion in an organ affected by a Th1-related auto-immune disease, namely PBC, is unclear.

To conclude, we described the first two cases of nodular lymphoid lesions of the liver with abundant IgG4+ plasma cells occurring in patients with PBC. It seems unlikely that these lesions are manifestation of IgG4related disease. However, because the pathogenesis of both nodular lymphoid lesions and IgG4-related disease remain unclear, studying IgG4+ plasma cell infiltrates in a larger number of nodular lymphoid lesions and determining the precise pathogenesis of IgG4-related disease are necessary.

\section{Acknowledgments}

The authors thank Dr Jacqueline Fontugne for her assistance in revising the manuscript.

\section{References}

1. Sharifi S, Murphy M, Loda M, Pinkus GS, Khettry U (1999) Nodular lymphoid lesion of the liver: an immune-mediated disorder mimicking low-grade malignant lymphoma Am J Surg Pathol 23:302-308

2. Takahashi H, Sawai H, Matsuo Y, Funahashi H, Satoh M, Okada Y, Inagaki H, Takeyama H, Manabe T (2006) Reactive lymphoid hyperplasia of the liver in a patient with colon cancer: report of two cases BMC gastroenterology 6:25

3. Zen Y, Fujii T, Nakanuma Y (2010) Hepatic pseudolymphoma: a clinicopathological study of five cases and review of the literature Mod Pathol 23:244-250 
4. Willenbrock K, Kriener S, Oeschger S, Hansmann ML (2006) Nodular lymphoid lesion of the liver with simultaneous focal nodular hyperplasia and hemangioma: discrimination from primary hepatic MALT-type non-Hodgkin's lymphoma Virchows Arch 448:223-227

5. Cheuk W, Lee KC, Chong LY, Yuen ST, Chan JK (2009) IgG4-related Sclerosing disease: a potential new etiology of cutaneous pseudolymphoma Am J Surg Pathol 33:1713-1719

6. Guinee DG, Jr., Franks TJ, Gerbino AJ, Murakami SS, Acree SC, Koss MN (2013) Pulmonary nodular lymphoid hyperplasia (pulmonary pseudolymphoma): the significance of increased numbers of IgG4positive plasma cells Am J Surg Pathol 37:699-709

7. Deshpande V, Zen Y, Chan JK, Yi EE, Sato Y, Yoshino T, Kloppel G, Heathcote JG, Khosroshahi A, Ferry JA, Aalberse RC, Bloch DB, Brugge WR, Bateman AC, Carruthers MN, Chari ST, Cheuk W, Cornell LD, Fernandez-Del Castillo C, Forcione DG, Hamilos DL, Kamisawa T, Kasashima S, Kawa S, Kawano M, Lauwers GY, Masaki Y, Nakanuma Y, Notohara K, Okazaki K, Ryu JK, Saeki T, Sahani DV, Smyrk TC, Stone JR, Takahira M, Webster GJ, Yamamoto M, Zamboni G, Umehara H, Stone JH (2012) Consensus statement on the pathology of IgG4-related disease Mod Pathol 25:1181-1192

8. van Dongen JJ, Langerak AW, Bruggemann M, Evans PA, Hummel M, Lavender FL, Delabesse E, Davi F, Schuuring E, Garcia-Sanz R, van Krieken JH, Droese J, Gonzalez D, Bastard C, White HE, Spaargaren M, Gonzalez M, Parreira A, Smith JL, Morgan GJ, Kneba M, Macintyre EA (2003) Design and standardization of PCR primers and protocols for detection of clonal immunoglobulin and T-cell receptor gene recombinations in suspect lymphoproliferations: report of the BIOMED-2 Concerted Action BMH4-CT98-3936 Leukemia 17:2257-2317

9. Zhang L, Lewis JT, Abraham SC, Smyrk TC, Leung S, Chari ST, Poterucha JJ, Rosen CB, Lohse CM, Katzmann JA, Wu TT (2010) IgG4+ plasma cell infiltrates in liver explants with primary sclerosing cholangitis Am J Surg Pathol 34:88-94

10. Strehl JD, Hartmann A, Agaimy A (2011) Numerous IgG4-positive plasma cells are ubiquitous in diverse localised non-specific chronic inflammatory conditions and need to be distinguished from IgG4related systemic disorders J Clin Pathol 64:237-243

11. Virk R, Shinagare S, Lauwers GY, Yajnik V, Stone JH, Deshpande V (2014) Tissue IgG4-positive plasma cells in inflammatory bowel disease: a study of 88 treatment-naive biopsies of inflammatory bowel disease Mod Pathol 27:454-459

12. Kimura Y, Harada K, Nakanuma Y (2012) Pathologic significance of immunoglobulin G4-positive plasma cells in extrahepatic cholangiocarcinoma Hum Pathol 43:2149-2156

13. Stone JH, Zen Y, Deshpande V (2012) IgG4-related disease N Engl J Med 366:539-551

14. Wong DD, Pillai SR, Kumarasinghe MP, McGettigan B, Thin LW, Segarajasingam DS, Hollingsworth PN, Spagnolo DV (2012) IgG4-related sclerosing disease of the small bowel presenting as necrotizing mesenteric arteritis and a solitary jejunal ulcer Am J Surg Pathol 36:929-934

15. Bateman AC, Ashton-Key MR, Jogai S (2015) Lymph node granulomas in IgG4-related disease Histopathology

16. Umemura T, Zen Y, Hamano H, Kawa S, Nakanuma Y, Kiyosawa K (2007) Immunoglobin G4hepatopathy: association of immunoglobin G4-bearing plasma cells in liver with autoimmune pancreatitis Hepatology 46:463-471 
17. Deshpande V, Sainani NI, Chung RT, Pratt DS, Mentha G, Rubbia-Brandt L, Lauwers GY (2009) IgG4-associated cholangitis: a comparative histological and immunophenotypic study with primary sclerosing cholangitis on liver biopsy material Mod Pathol 22:1287-1295

18. Chung H, Watanabe T, Kudo M, Maenishi O, Wakatsuki Y, Chiba T (2010) Identification and characterization of IgG4-associated autoimmune hepatitis Liver Int 30:222-231

19. Yang CY, Ma X, Tsuneyama K, Huang S, Takahashi T, Chalasani NP, Bowlus CL, Yang GX, Leung PS, Ansari AA, Wu L, Coppel RL, Gershwin ME (2014) IL-12/Th1 and IL-23/Th17 biliary microenvironment in primary biliary cirrhosis: implications for therapy Hepatology 59:1944-1953

20. Miyake K, Moriyama M, Aizawa K, Nagano S, Inoue Y, Sadanaga A, Nakashima H, Nakamura S (2008) Peripheral CD4+ T cells showing a Th2 phenotype in a patient with Mikulicz's disease associated with lymphadenopathy and pleural effusion Modern rheumatology / the Japan Rheumatism Association 18:86-90

21. Zen Y, Fujii T, Harada K, Kawano M, Yamada K, Takahira M, Nakanuma Y (2007) Th2 and regulatory immune reactions are increased in immunoglobin G4-related sclerosing pancreatitis and cholangitis Hepatology 45:1538-1546 
